Revista Monografias Ambientais - REMOA v. 15, n.1, jan-abr. 2016, p.302-322

Revista do Centro de Ciências Naturais e Exatas - UFSM, Santa Maria

\title{
O PROGRAMA RIO RURAL NO ESTADO DO RIO DE JANEIRO: A EXPERIÊNCIA NA MICROBACIA CANAL JURUMIRIM, MUNICÍPIO DE MACAÉ
}

The Rio Rural program in Rio de Janeiro state: the Canal Jurumirim microbasin experience, Macaé county

\section{Ana Rita Moreira Rangel ${ }^{1}$, Vicente de Paulo Santos de Oliveira ${ }^{2}$ e Marcos Antonio Cruz Moreira $^{3}$}

\author{
${ }^{1}$ Emater - RJ, Macaé, RJ, Brasil \\ 2 IFF, Campos dos Goytacazes, RJ, Brasil \\ ${ }^{3}$ IFF, Macaé, RJ, Brasil
}

Resumo

\begin{abstract}
Do ponto de vista físico, microbacia hidrográfica é uma unidade geográfica delimitada por uma rede de drenagem (córregos) que deságua em um rio principal. O Rio Rural é um programa de financiamento que usa a metodologia participativa para sua implementação. No início do processo os membros da microbacia se reuniram em grupos de interesse elegendo seus representantes para comporem o chamado Comitê Gestor da Microbacia, o COGEM, que acompanhará o técnico executor em todas as fases do programa, até o controle. Várias práticas são incentivadas, entre elas a Proteção de nascentes (isolamento com cerca); A comunidade trabalhada nesse estudo é o Assentamento Prefeito Celso Daniel, que possui 204 famílias. Já foram elaborados 35 PIDs (Planos Individuais de Desenvolvimento) e liberados aproximadamente $R \$$ 89.098,00 em recursos, com incentivo de 38 subprojetos. Observou-se que de modo geral a comunidade encontra-se satisfeita com o incentivo financeiro proporcionado pelo programa. A percepção do ganho ambiental é bastante alta, bem como ansiedade dos envolvidos em que todos sejam contemplados pois são muitas famílias na microbacia em questão. O maior problema atualmente são os beneficiários que se encontram com as prestações de contas e implantação dos projetos fora dos prazos estipulados.
\end{abstract}

Palavras-chave: Agricultura familiar. Ambiental. Metodologia participativa.

Abstract

The microbasin is a geographical unit bounded by a drainage network (small rivers) that lead to a main river. The Rio Rural program is a financial one and utilizes participative methodology. In the beginning of the process members of the microbasin joined together in interest related groups to elect their representatives to compose the so called Microbasin Manager Committee, the COGEM, which would follow the executor technician during all the program phases, even control. Various practices are supported, among them there is water spring protection. The community in this study is Prefeito Celso Daniel settlement, which has 204 families. 35 PIDs (Individual Development Plans) have been made and near R\$ 89.098,00 financed split in 38 subprojects. In general, it was observed that the community is satisfied with the financial incentive given by the program. The sense of environmental gain is high enough, as well as the anxiety of the people involved that everyone accesses it for the numerous families. The biggest problem faced nowadays is the beneficiaries that are current out of stipulated deadline for the accountability and subprojects implementing.

Keywords: Family farming. Environmental. participatory methodolog 


\section{Introdução}

O Programa de Desenvolvimento Rural Sustentável em Microbacias Hidrográficas do Estado do Rio de Janeiro - RIO RURAL - tem como grande desafio a melhoria da qualidade de vida no campo, conciliando o aumento da renda do produtor rural com a conservação dos recursos naturais. Visa aumentar a adoção de abordagens integradas e sustentáveis em sistemas produtivos do setor rural e dar suporte ao aumento da produtividade e competitividade da agricultura fluminense. Para atingir este objetivo, desenvolveu uma estratégia de ação que utiliza a microbacia hidrográfica como unidade de planejamento e intervenção, envolvendo diretamente as comunidades residentes neste espaço geográfico.

Desta forma, este estudo tem como objetivos determinar a situação atual das nascentes que estão em propriedade de beneficiários envolvidos no Programa Rio Rural, contemplados com o subprojeto proteção e recuperação de nascentes, bem como verificar a potabilidade e qualidade dessas águas, e das outras fontes usadas para consumo humano, animal e o uso agrícola. Neste trabalho faz-se uma descrição do projeto Rio Rural no Rio de Janeiro, a sua metodologia e andamento, com ênfase nas experiências adquiridas no trabalho junto à comunidade do assentamento Prefeito Celso Daniel, na microbacia Canal Jurumirim, de Macaé. Os Trabalhos futuros terão como objetivo a determinação da vazão de nascentes protegidas pelo projeto Rio Rural e qualidade dessas mesmas águas, além daquelas de uso humano, animal e de irrigação.

\section{Revisão de literatura}

\subsection{O programa Rio Rural}

Com financiamento do Banco Mundial (Banco Internacional para a Reconstrução e Desenvolvimento - BIRD), que firmou acordo com o Governo do estado do Rio de Janeiro, o Rio Rural incentiva a adoção de práticas sustentáveis e técnicas produtivas mais eficientes e ambientalmente adequadas (RIO RURAL, 2009).

O Rio Rural vê o homem do campo como protagonista no processo de desenvolvimento. Por isso, promove a participação comunitária nas políticas públicas e gestão de recursos naturais, buscando a conscientização e adesão do produtor às práticas sustentáveis. Por outro lado, defende que o agricultor familiar seja compensado pela limitação do uso dos recursos naturais impostas pelas políticas de conservação (RIO RURAL, 2009).

Para o cálculo de beneficiários e valores, o projeto possui as seguintes categorias: beneficiários de projetos produtivos e ambientais; beneficiários de saneamento e beneficiários de estradas. Esses controles são feitos separadamente e podem ter superposição, e hoje contabilizam juntos, 25.300 subprojetos implantados.

São beneficiadas ainda as populações residentes nos centros urbanos e na Região Metropolitana do Rio de Janeiro, pelo aumento na oferta de alimentos e água, diminuição da pressão por emprego, saúde e moradia, além de ações de educação ambiental (RIO RURAL, 2009).

Assim foi com o evento intitulado Caravana Agroecológica e Cultural da Região Metropolitana, que ocorreu de 19 a 21 de novembro de 2013, englobando os municípios da região metropolitana do 
Rio de Janeiro. Foram feitas visitas em áreas de agricultura urbana, além de contemplar atividades culturais, feiras e debates. Nos três dias de atividades, contou com a presença de agricultores e agricultoras, associações de produtores rurais, organizações e estudantes. Os presentes também tiveram espaços para o debate sobre as questões de conflito ambiental e territorial nesta região, que mesmo tendo 99,7\% de sua população em área urbana, busca o fortalecimento de sua agricultura e dos agricultores que ainda permanecem neste território.

São feitas ações conjuntas, como essa parceria de agosto de 2012 na qual os alunos da rede municipal de ensino de Itaperuna utilizam biblioteca e laboratório de informática da EMATER - RIO, bem com interação junto aos técnicos da instituição. São também realizadas palestras nas escolas e visitas em campo.

\subsection{Metodologia de microbacias hidrográficas}

A bacia hidrográfica é uma unidade geográfica constituída por uma área da superfície terrestre que contribui na sua formação e no armazenamento de determinado curso d'água. As bacias de cabeceiras são pequenas áreas de terras localizadas em regiões montanhosas, onde se formam as nascentes e drenam córregos e riachos. Uma bacia hidrográfica, normalmente, é constituída por inúmeras microbacias, que por sua vez possuem inúmeros pequenos riachos que formam a malha de drenagem dessa bacia (Alves, 2000). Do ponto de vista físico, a microbacia hidrográfica é uma unidade geográfica delimitada por uma rede de drenagem (córregos) que deságua em um rio principal. A microbacia está associada à realização de programas de desenvolvimento sustentável, tendo como beneficiários diretos comunidades rurais.

A metodologia de trabalho em microbacias hidrográficas vem sendo aprimorada no Brasil nos últimos 20 anos e busca a autogestão comunitária dos recursos naturais através da adoção de práticas de manejo sustentável pelas comunidades rurais.

As práticas de conservação de solo e água promovidos pelo Rio Rural consolidam o reconhecimento desta metodologia como um instrumento ambiental, ampliando suas possibilidades de adoção por atores e financiadores não agrícolas (RIO RURAL, 2009).

\subsubsection{Princípios da metodologia de microbacias hidrográficas}

A) Descentralização e Participação da comunidade na priorização das ações: Até o final dos anos 1970 os levantamentos de dados, tanto em áreas rurais como urbanas eram feitos através de métodos convencionais, como a aplicação de questionários padronizados para as diferentes categorias dentro de uma população. Geralmente eram escolhidas as pessoas mais importantes, ou mais expressivas politicamente como informantes dessas pesquisas. Os pesquisadores coletavam os dados a campo e só depois retornavam com esses dados, já ultrapassados, as comunidades. Esse conhecimento, muitas vezes já não servia mais para a realidade local. Além disso, a população em geral, principalmente a mais pobre, não expunha suas problemáticas (KUMMER, 2007).

Quando esses dados coletados nessas áreas viravam subsídios para políticas públicas, essas políticas normalmente fracassavam, pois representavam apenas parte da população e não tinham a adesão de mais beneficiários, que muitas vezes nem sabiam o porquê daquela ação.

No intuito de mudar esta metodologia de coleta de dados, os órgãos responsáveis por assistir áreas rurais começaram a utilizar os conceitos da educação popular e participação preconizados por Paulo Freire no Brasil. Assim, surgem dentro deste panorama, as metodologias participativas que são entendidas como um processo contínuo de troca de informações entre os pesquisadores (chamados agora de mediadores) e todas as categorias a serem investigadas. A metodologia participativa se torna 
um processo dinâmico, uma vez que precisa ser adaptada, a cada instante, de acordo com as respostas, de acordo com cada grupo alvo e os problemas da sua realidade (KUMMER, 2007).

Na década de 1980/1990, os agentes de extensão rural começam utilizar-se do Diagnóstico Rural Participativo (DRP). O DRP “é um conjunto de técnicas e ferramentas que permite que as comunidades façam o seu próprio diagnóstico e a partir daí comecem a autogerenciar o seu planejamento e desenvolvimento" (VERDEJO, 2007). Assim, as diferentes categorias dentro de uma comunidade podem participar, compartilhar experiências e analisar os seus próprios conhecimentos, a fim de melhorar as suas habilidades de planejamento e ação.

O DRP pretende desenvolver processos de pesquisa e desenvolvimento a partir das condições e das possibilidades dos participantes. A metodologia tem como base a opinião e os conceitos do participante e o não enfrentamento a partir de questionamentos pré-formulados. A idéia é que os próprios participantes analisem a sua situação e valorizem diferentes opções para melhorá-la. Assim a reflexão-ação é a forma de aquisição de conhecimentos no DRP. Com isso, além de gerar dados, o diagnóstico permite a auto-reflexão da comunidade sobre os seus problemas e assim possibilita a ela encontrar os caminhos internos para solucioná-los. A intervenção de pessoas externas ao grupo é mínima, apenas mediando os debates dentro do grupo (VERDEJO, 2007, KUMMER, 2007).

B) Transparência das decisões, acesso às informações sobre investimentos e fortalecimento organizacional: No início do processo, são eleitos membros da microbacia, que se reúnem em grupos de interesse elegendo seus representantes para comporem o chamado Comitê Gestor da Microbacia, o COGEM, que acompanhará o técnico executor em todas as fases do programa, até o controle. Hoje são 243 COGEMs em ação. As reuniões na microbacia e as visitas individuais geram por sua sistematização os 225 DRPs elaborados até hoje e que serviram de base para a elaboração de 216 Planos Executivos da Microbacia - documento que sintetiza os problemas e desejos da comunidade. Todos foram apresentados aos membros da microbacia em reuniões públicas e submetidos à aprovação e melhorias. Os temas que mais se destacam são serviços básicos (educação e saúde), saneamento e infraestrutura. Esses temas aparecem em quase todos os DRPs.

C) Estímulo às formas organizativas para a profissionalização (associativismo e cooperativismo); Sustentabilidade e Equilíbrio entre as dimensões social, econômica e ambiental: O Rio Rural prioriza a execução de projetos grupais, dentre os quais podemos destacar alguns, constantes na Tabela 1 abaixo:

Tabela 1 - Relação de práticas incentivadas em subprojetos coletivos classificadas como ambientais e consideradas como estruturantes. Fonte: Elaboração própria.

\begin{tabular}{|l|c|c|c|l|}
\hline PRÁTICA & 1 & 2 & 3 & ÍTENS \\
\hline $\begin{array}{l}\text { Captação e } \\
\text { distribuição de água } \\
\text { potável - (GRUPAL) }\end{array}$ & 25.000 & 20.000 & 20.000 & $\begin{array}{l}\text { Instalação de depósito e cisterna elevada, } \\
\text { aquisição de bomba, tubulação e conexões }\end{array}$ \\
\hline $\begin{array}{l}\text { Compostagem e } \\
\text { vermicompostagem } \\
\text { (grupal) }\end{array}$ & 16.000 & 12.800 & 12.800 & $\begin{array}{l}\text { Material: cimento, areia, brita, sombrite, } \\
\text { bambu, tela de arame, enxada, enxadão, } \\
\text { enxada ou pá em tridente, carrinho de mão, } \\
\text { mangueira, vara de cano PVC esgoto 50 } \\
\text { mm, telha fibra opaca, minhoca e triturador } \\
\text { mecânico. }\end{array}$ \\
\hline
\end{tabular}




\begin{tabular}{|l|c|c|c|c|}
\hline $\begin{array}{l}\text { Construção de } \\
\text { açudes coletivos }\end{array}$ & 13.000 & 10.400 & 10.400 & $\begin{array}{l}\text { Serviços de máquinas até } \\
\text { horas/máquina (incluído deslocamento de } \\
\text { máquinas e pessoal) }\end{array}$ \\
\hline $\begin{array}{l}\text { Incentivo à educação } \\
\text { ambiental }\end{array}$ & 2.500 & 2.000 & 2.000 & $\begin{array}{l}\text { Materiais diversos de papelaria e e } \\
\text { compatíveis para uso em processos de } \\
\text { reciclagem, mudas, sementes, insumos } \\
\text { agrícolas, ferramentas e utensílios, máquina } \\
\text { fotográfica (limitado a R } \$ 700,00) .\end{array}$ \\
\hline $\begin{array}{l}\text { Instalação de poços } \\
\text { tubulares profundos, } \\
\text { reservatório e redes } \\
\text { de distribuição de } \\
\text { água, de uso coletivo } \\
\text { (min. 10 famílias). }\end{array}$ & 100.000 & 80.000 & 80.000 & $\begin{array}{l}\text { Serviços de perfuração e instalação de } \\
\text { poço tubular profundo, com reservatório e } \\
\text { rede de distribuição. }\end{array}$ \\
\hline $\begin{array}{l}\text { Produção } \\
\text { Biofertilizantes - } \\
\text { Grupal }\end{array}$ & 4.000 & 3.200 & 3.200 & $\begin{array}{l}\text { Bombonas de 200 litros ou caixas d'água } \\
\text { de } \\
\text { mão, sombrite ou malha para peneira fina. }\end{array}$ \\
\hline
\end{tabular}

Legenda:

1 - Valor total da prática, em reais.

2 - Valor liberado pelo projeto para o agricultor classificado como agricultor familiar, segundo critérios do PRONAF, em reais.

3 - Valor, em reais, liberado pelo programa para os demais agricultores

Esses projetos acima citados têm maior peso em relação aos subprojetos individuais que possuem por princípio a adoção de pelo menos uma das seguintes práticas ambientais, como fundamentais, sem as quais não são feitos subprojetos produtivos. As práticas ambientais estruturantes estão elencadas na Tabela 2 abaixo:

Tabela 2 - Relação de práticas incentivadas em subprojetos individuais classificadas como ambientais e consideradas como estruturantes. Fonte: Elaboração própria.

\begin{tabular}{|l|c|c|c|l|}
\hline PRÁTICA & 1 & 2 & 3 & ÍTENS \\
\hline $\begin{array}{l}\text { Implantação de Sistema } \\
\text { Agroflorestal }\end{array}$ & 5.750 & 4.600 & 4.600 & $\begin{array}{l}\text { Composto orgânico, húmus, cama de frango } \\
\text { (exceto esterco de curral), corretivos, mudas, } \\
\text { material de cerca. }\end{array}$ \\
\hline $\begin{array}{l}\text { Proteção de nascentes - } \\
\text { (isolamento com cerca) }\end{array}$ & 3.500 & 2.800 & 2.800 & $\begin{array}{l}\text { Material de cerca (mourão, arame farpado e } \\
\text { grampo) }\end{array}$ \\
\hline $\begin{array}{l}\text { Recuperação da mata } \\
\text { ciliar c/ cercamento e }\end{array}$ & 6.000 & 4.800 & 4.800 & $\begin{array}{l}\text { Material de cerca (mourão, arame farpado e } \\
\text { grampo), mudas de nativas da mata atlântica }\end{array}$ \\
\hline
\end{tabular}




\begin{tabular}{|l|l|l|l|l|}
\hline plantio. & & & & $\begin{array}{l}\text { e frutíferas, fertilizantes orgânicos e minerais } \\
\text { fosfatados). }\end{array}$ \\
\hline $\begin{array}{l}\text { Recuperação de área de } \\
\text { recarga c/cercamento e } \\
\text { plantio. }\end{array}$ & 6.500 & 5.200 & 5.200 & $\begin{array}{l}\text { Material de cerca (mourão, arame farpado e } \\
\text { grampo), Mudas de nativas e frutíferas } \\
\text { nativas da mata atlântica, fertilizantes } \\
\text { orgânicos e minerais fosfatados). }\end{array}$ \\
\hline
\end{tabular}

Legenda:

1 - Valor total da prática, em reais.

2 - Valor, em reais, liberado pelo programa para o agricultor classificado como agricultor familiar, segundo critérios do PRONAF.

3 - Valor em reais liberado pelo programa para os demais agricultores.

Estão disponíveis várias outras práticas de cunho ambiental e outras, classificadas como produtivas sustentáveis, das quais podemos citar: Animais de tração e apetrechos (aquisição) Individual; Aquisição de matrizes caprinas - 03 p/beneficiário; Aquisição de volumosos para arraçoamento emergencial de rebanhos; Barragem subterrânea; Empreendedorismo do jovem rural; Equipamento de irrigação para culturas permanentes e pastagens; Empreendimentos artesanais de pequena escala; Equipamento para geração de energia - Individual; Estrutura para seleção/processamento/benef/secagem/ armazenagem - individual; Formação de Pastagem (1,0 ha); Kit Apicultura /Meliponicultura; Kit Galinha Caipira; Ordenhadeira mecânica (conjunto com 2 ou 4 teteiras); Pastoreio rotacionado; entre outras.

É importante ressaltar que todos os subprojetos estão inseridos no contexto das priorizações e demandas verificadas nos Diagnósticos Rurais Participativos e constantes nos Planos Executivos da Microbacia, que são os documentos orientadores da ação dos técnicos executivos. Por ocasião da elaboração dos subprojetos, é feita pelo menos uma visita e/ou reunião com os agricultores e decidido em conjunto qual subprojeto será elegido, respeitando sempre a vontade dos agricultores envolvidos.

Foram mapeadas 610 microbacias, das quais 266 já estão sendo trabalhadas; no entanto, esse número sofrerá alteração, porque algumas delas estão se fundindo.

\subsection{Estrutura do programa}

O programa Rio Rural está estruturado compreendendo três fases distintas, quais sejam a sensibilização, planejamento e execução, como ilustrado na Figura 1: 


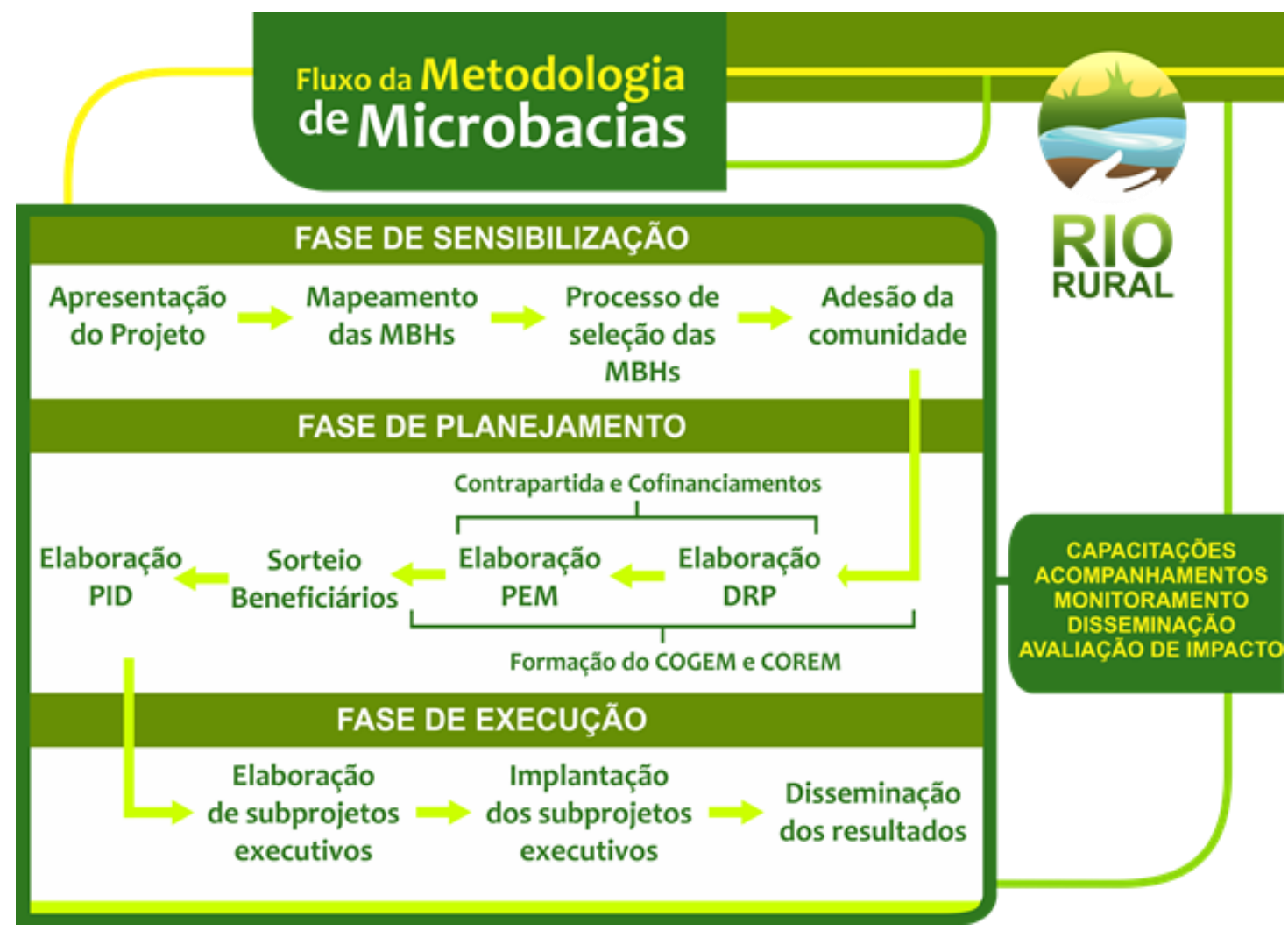

Figura 1 - Quadro de fluxograma na metodologia de microbacias hidrográficas utilizado pelo programa Rio Rural. Fonte: site oficial do programa.

Executado pela Secretaria de Agricultura e Pecuária do Estado do Rio de Janeiro (SEAPEC) através da Superintendência de Desenvolvimento Sustentável (SDS), o programa tem como parceiros:

- Conservação Internacional Brasil;

- DRM-RJ - Departamento de Recursos Minerais do Estado do Rio de Janeiro;

- DPGE - Defensoria Pública do estado do Rio de Janeiro;

- EMATER-RIO - Empresa de Assistência Técnica e Extensão Rural do estado do Rio de Janeiro;

- $\quad$ EMBRAPA - Empresa Brasileira de Pesquisa Agropecuária;

- FIPERJ - Fundação Instituto de Pesca do estado do Rio de Janeiro;

- INEA - Instituto Estadual do Ambiente;

- PESAGRO-RIO - Empresa de Pesquisa Agropecuária do estado do Rio de Janeiro;

- Prefeituras Municipais;

- PRODERJ - Centro de Tecnologia da Informação e Comunicação do Estado do Rio de Janeiro;

- SEA - Secretaria de Estado do Ambiente; 
- SEDEC - Secretaria de Estado de Defesa Civil;

- SEEDUC - Secretaria de Estado de Educação;

- SES - Secretaria de Estado de Saúde;

- SOS Mata Atlântica;

- UENF - Universidade Estadual do Norte Fluminense Darcy Ribeiro;

- UERJ - Universidade Estadual do Rio de Janeiro;

São usados os seguintes instrumentos de controle: avaliações periódicas nas propriedades (supervisões e auditorias); termos de responsabilidade e cobranças jurídicas.

\subsubsection{As duas fases do programa:}

\subsubsection{Rio Rural GEF}

O Programa de Gerenciamento Integrado de Agroecossistemas em Microbacias Hidrográficas do Norte e Noroeste Fluminense - RIO RURAL GEF vem sendo realizado desde 2005 em 50 microbacias hidrográficas do Estado do Rio de Janeiro, com o objetivo de promover o manejo integrado de ecossistemas de importância global de mata de Mata Atlântica, através da autogestão sustentável dos recursos naturais por comunidades rurais de base familiar (RIO RURAL, 2009).

Com US\$ 6,5 milhões em recursos do Fundo Mundial para o Meio Ambiente (GEF), agenciados através do Banco Internacional para a Reconstrução e o Desenvolvimento (BIRD), o RIO RURAL GEF é considerado um marco para os Programas de Microbacias, pois pela primeira vez um programa coordenado pela Agricultura teve acesso a um fundo ambiental (RIO RURAL, 2009).

Através de um investimento total de US\$14 milhões, o Rio Rural GEF conscientiza seus beneficiários sobre os temas que afetam suas vidas, cria oportunidades econômicas ambientalmente sustentáveis para as comunidades rurais, e como fortalece a coesão social e o empoderamento de 48 comunidades de microbacias das regiões administrativas do Norte e Noroeste, para que participem ativamente da tomada de decisões locais e do processo de desenvolvimento.

Ao evidenciar os benefícios e serviços ambientais prestados a partir da conscientização dos agricultores e melhoria de suas práticas, o programa busca identificar novas fontes de recursos, propondo que os produtores adotem práticas conservacionistas como contrapartida às políticas públicas de crédito e apoio à Agricultura. O programa Rio Rural GEF introduz ainda a preocupação com a sustentabilidade financeira das práticas de conservação, aprimorando os instrumentos de apoio financeiro em curso, como o rebate ambiental do crédito rural, o acesso aos recursos pela cobrança da água, o mercado de créditos de carbono etc. Em outras palavras, os Programas de Microbacias poderão funcionar como elo entre a agricultura familiar e as questões globais como biodiversidade, água e carbono (RIO RURAL, 2009).

Com objetivo de apoiar a adoção do Manejo Integrado de Ecossistemas (MIE), contribuindo para a diminuição das ameaças à biodiversidade, a inversão do processo de degradação das terras e o aumento dos estoques de carbono na paisagem agrícola em ecossistemas críticos e únicos de importância global da Mata Atlântica do Norte e Noroeste Fluminense, através do Manejo Sustentável dos Recursos Naturais (MSRN) por comunidades rurais, utilizando a microbacia hidrográfica como unidade de planejamento. Os municípios participantes são: Campos dos Goytacazes, Carapebus, Cardoso Moreira, Conceição de Macabu, Macaé, Quissamã, São Fidélis, São Francisco do Itabapoana, 
São João da Barra, Santa Maria Madalena, Trajano de Morais, Aperibé, Bom Jesus do Itabapoana, Cambuci, Italva, Itaocara, Itaperuna, Laje do Muriaé, Miracema, Natividade, Porciúncula, Santo Antônio de Pádua, São José de Ubá e Varre-Sai.

Esta conquista vem possibilitando ao Rio Rural demonstrar que as práticas dos agricultores geram impactos significativos no meio ambiente e podem contribuir para mitigar alguns dos principais efeitos nocivos ao planeta, como a diminuição da biodiversidade, o aquecimento global, a poluição, o desaparecimento dos rios e a degradação dos solos. O Rio Rural GEF foi operacionalizado até 2010, e a partir daí, são feitos os acompanhamentos de todos os subprojetos implantados.

\subsubsection{Rio Rural BIRD}

O Programa de Desenvolvimento Rural Sustentável em Microbacias Hidrográficas do Estado do Rio de Janeiro - RIO RURAL BIRD, aprovado pelo Banco Mundial em 2009, ampliou as ações do Programa Rio Rural para todas as regiões do Estado. O seu objetivo é promover o desenvolvimento sustentável do setor rural e a diminuição das ameaças ao meio ambiente, através da adequação dos sistemas produtivos e do apoio a atividades que visam elevar a produtividade e a competitividade da agricultura familiar (RIO RURAL, 2009).

O RIO RURAL BIRD investirá US\$79 milhões em ações sustentáveis em 270 microbacias hidrográficas de 59 municípios até o final de 2015, sendo US\$39,5 milhões investidos pelo Estado do Rio de Janeiro e a outra metade financiada pelo Banco Internacional para a Reconstrução e o Desenvolvimento (BIRD). Distribuído pelos municípios:

Região Norte - Campos dos Goytacazes, Carapebus, Cardoso Moreira, Conceição de Macabu, Macaé, Quissamã, São Fidélis, São Francisco de Itabapoana e São João da Barra;

Região Noroeste - Aperibé, Bom Jesus do Itabapoana, Cambuci, Italva, Itaocara, Itaperuna, Laje do Muriaé, Miracema, Natividade, Porciúncula, Santo Antônio de Pádua, São José de Ubá, Varre-Sai;

Região Serrana - Bom Jardim, Cantagalo, Carmo, Cordeiro, Duas Barras, Macuco, Nova Friburgo, Petrópolis, Santa Maria Madalena, São José do Vale do Rio Preto, São Sebastião do Alto, Sumidouro, Teresópolis, Trajano de Morais;

Região Centro - Araruama, Cabo Frio, Cachoeiras de Macacu, Casimiro de Abreu, Rio Bonito, Saquarema, Silva Jardim, Tanguá, Itaboraí, Itaguaí, Magé, Mangaratiba, Paracambi, São Gonçalo, Seropédica;

Região Sul - Paty do Alferes, Sapucaia, Vassouras, Piraí, Quatis, Rio Claro, Rio das Flores e Valença.

Hoje, o programa está previsto para atuação até 2018. A figura 2 mostra a divisão por regiões no mapa do estado do Rio de Janeiro. 


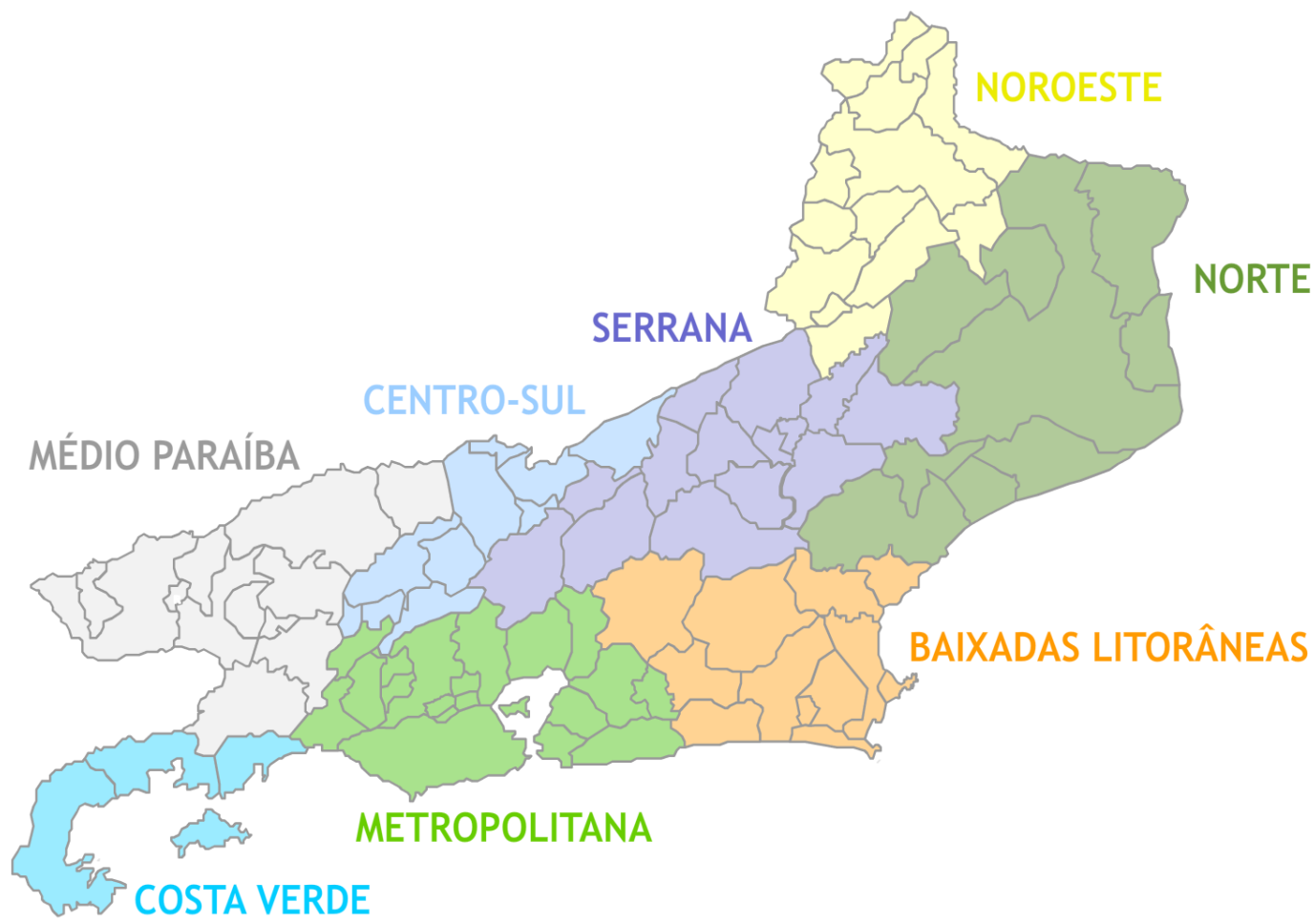

Figura 2 - Divisão das regiões pelo programa Rio Rural. Fonte: site oficial do programa Rio Rural.

\subsection{Metodologia Utilizada na Priorização dos Municípios do Programa de Financiamento}

Para a seleção dos municípios baseou-se em critérios socioeconômicos e ambientais que possibilitaram atender aos seguintes objetivos do Programa:

1. Expansão ampla e abrangente da estratégia de Práticas de Manejo Sustentável de Recursos Naturais nas microbacias hidrográficas adotada no RIO RURAL GEF;

2. Redução da pobreza rural e melhoria das condições de vida no meio rural;

3. Apoio à promoção da agricultura familiar sustentável;

4. A inversão dos processos de degradação ambiental.

Foi acordado, com o Banco Mundial, a aplicação de critérios que melhor descrevessem a importância da agricultura familiar na economia local, a pobreza e a degradação ambiental. Os índices aplicados em todos os municípios do Estado do Rio de Janeiro, considerou:

a. $\mathrm{N}^{\circ}$ de agricultores familiares (fonte MDA/ SADE - Banco de Dados da agricultura familiar 2006);

b.№. Agricultores familiares de Baixa renda ou quase sem renda (fonte MDA/ SADE - Banco de Dados da agricultura familiar 2006);

c.IDH municipal (Fonte: Fundação CIDE - IDH-M 2008);

d.Índices de IQM Verde (invertido) (Fonte CIDE IQM-Verde 2005);

e.Participação do setor agropecuário na composição do PIB municipal (\%) (CIDE 2008); 
f.Concentração de população rural (\%) (Fonte CEPERJ - população rural).

Após pontuação, os municípios foram elencados em ordem decrescente de pontuação, sendo os melhor pontuados os que seriam atendidos primeiro, como observado na Tabela 3:

Tabela 3 - Municípios selecionados na área focal de Prioridade 1 do Programa (Norte e Noroeste)

\begin{tabular}{|c|c|c|c|c|c|c|}
\hline $\mathrm{A}$ & B & $\mathrm{C}$ & $\mathrm{D}$ & E & $\mathrm{F}$ & G \\
\hline 1 & 34 & $\mathrm{~N}$ & São Francisco de Itabapoana & 8 & 984 & $1.122,30$ \\
\hline 2 & 34 & $\mathrm{NO}$ & Varre-Sai & 7 & 1024 & 190,7 \\
\hline 3 & 31 & $\mathrm{NO}$ & Porciúncula & 7 & 1111 & 301,5 \\
\hline 4 & 31 & $\mathrm{NO}$ & São José de Ubá & 7 & 1046 & 251,6 \\
\hline 5 & 30 & $\mathrm{NO}$ & Itaocara & 12 & 949 & 428,7 \\
\hline 6 & 29 & $\mathrm{~N}$ & Carapebus & 7 & 557 & 310,6 \\
\hline 7 & 29 & $\mathrm{~N}$ & São Fidélis & 9 & 761 & $1.035,60$ \\
\hline 8 & 28 & $\mathrm{~N}$ & Cardoso Moreira & 8 & 627 & 517,2 \\
\hline 9 & 28 & $\mathrm{NO}$ & Italva & 5 & 544 & 294,8 \\
\hline 10 & 28 & $\mathrm{NO}$ & Laje do Muriaé & 6 & 472 & 251,6 \\
\hline 11 & 27 & $\mathrm{~N}$ & Quissamã & 6 & 290 & 724,2 \\
\hline 12 & 27 & $\mathrm{NO}$ & Bom Jesus do Itabapoana & 7 & 403 & 599,4 \\
\hline 13 & 27 & $\mathrm{NO}$ & Natividade & 5 & 401 & 390,6 \\
\hline 14 & 26 & $\mathrm{~N}$ & Campos dos Goytacazes & 14 & 2460 & $4.040,60$ \\
\hline 15 & 26 & $\mathrm{NO}$ & Itaperuna & 14 & 1287 & $1.109,50$ \\
\hline 16 & 26 & $\mathrm{NO}$ & Santo Antônio de Pádua & 12 & 1760 & 610,7 \\
\hline 17 & 24 & $\mathrm{NO}$ & Cambuci & 11 & 1518 & 561,6 \\
\hline 18 & 23 & $\mathrm{~N}$ & São João da Barra & 6 & 1181 & 457,8 \\
\hline 19 & 23 & $\mathrm{NO}$ & Miracema & 6 & 639 & 302,5 \\
\hline 20 & 20 & $\mathrm{~N}$ & Macaé & 9 & 574 & $1.219,80$ \\
\hline 21 & 18 & $\mathrm{~N}$ & Conceição de Macabu & 2 & 251 & 338,9 \\
\hline 22 & 0 & $\mathrm{NO}$ & Aperibé & 4 & 166 & 92,4 \\
\hline
\end{tabular}




\begin{tabular}{|l|l|l|l|l|l|}
\hline TOTAL & & 22 municípios & 172 & 19.005 & $15.152,6$ \\
\hline
\end{tabular}

Legenda: A - Classificação; B - Pontos; C - Região; D - Município; E - № MBHs; F - № Famílias e G Área. Elaboração própria.

\subsection{Proteção de Nascentes}

Dentre os vários subprojetos incentivados está a prática de proteção de nascentes, que consiste em liberação de recursos não reembolsáveis para cercamento e isolamento de nascentes pelos proprietários rurais, que em contrapartida se comprometem a executar o programa e por ele zelar por período estipulado em compromisso firmado com o Programa. Os agricultores contemplados têm financiado $80 \%$ do valor total dos projetos ambientais, e os outros $20 \%$ são a contrapartida, normalmente em mão de obra. Hoje, a prática está orçada em $R \$ 3.500,00$ dos quais $R \$ 700,00$ são a contrapartida. No período 2008-2012, o Rio Rural protegeu mais de mil nascentes com apoio de agricultores familiares, extensionistas rurais, prefeituras, empresas privadas, Comitês de Bacias Hidrográficas e outros parceiros nacionais e internacionais.

A disponibilidade hídrica em corpos d'água e reservas de água potável do meio rural é fundamental, não só para o desenvolvimento das atividades agropecuárias, como também para o abastecimento dos centros urbanos, para a produção industrial e para a geração de energia (Ramos et al., 2004). A largura da faixa de mata ciliar presente ao longo das margens dos rios e ao redor de nascentes e de reservatórios a ser preservada deverá estar relacionada com a largura do curso d'água. No caso das nascentes (mesmo intermitentes) e olhos d'água, essa faixa deve ter, no mínimo, um raio de 50m (Brasil, 1965). A construção de cercas fechando a área da nascente evita o pisoteio, a compactação do solo e a destruição das mudas e espécies em regeneração por animais existentes na área, como o gado, porcos, galinhas e outros.

No trabalho de PINTO ET AL (2012) a presença de vegetação ciliar na nascente perturbada auxiliou na proteção quali-quantitativa de seus recursos hídricos, ao longo dos períodos de amostragem, em comparação às nascentes com pastagem, com café, com policultivo e com casas, sendo as características cor, turbidez, coliformes totais e termotolerantes, DBO, fosfato total, nitrato e $\mathrm{OD}$ as que mais evidenciaram essas diferenças. Aquela com pastagem foi a que se apresentou mais degradada em decorrência do avançado estágio de erosão causando significativa alteração da cor e turbidez. No cultivo de café, a presença de atividade agropecuária com emprego de defensivos agrícola afetaram os níveis de oxigênio dissolvido e de fosfato total na água. Devido a presença de casas, os fatores de comprometimento da qualidade da água foram a ausência de mata ciliar e a presença de residências com fossas negras ao seu entorno, fator que pode ser responsabilizado pelo excesso de nitrogênio presente nesse reservatório.

Grande discussão se levanta sobre o tema de proteção de nascentes pois se pondera sobre a necessidade, viabilidade ou conveniência de se enriquecer a área do entorno com outras espécies. De Souza et al.(2012) avaliando o potencial de regeneração da vegetação no entorno de nascentes que foram protegidas, observaram que a densidade de indivíduos na regeneração sobdossel foi muito superior à encontrada na área aberta, mesmo 51 meses após o início da recuperação, indicando a existência de aspectos restritivos à regeneração na área de pastagem abandonada. A presença de gramíneas invasoras na área aberta constitui-se a maior dificuldade encontrada para a recuperação d o 
local, onde a regeneração natural apresenta-se de forma incipiente e lenta, o que permite inferir que a utilização da regeneração natural como metodologia exclusiva de recuperação não deve ser aplicada a esse ambiente.

Outro fator a se considerar é o uso pretendido para a água. Como se encontra em uma zona rural, uma das possibilidades é aproveitar essa água para irrigação. Mas qual a porcentagem da água pode ser usada é função da vazão da nascente, a qual pode variar de acordo com a época do ano e estar subordinada aos regimes de chuvas mais ou menos intensas na região. A respeito da qualidade, outra consideração é determinar a viabilidade, dimensionamento e tipo de irrigação a ser recomendada.

A respeito do método de irrigação a ser implantado, como demonstram Franco \& Hernandez (2009), os resultados de pesquisa indicam que os parâmetros físico-químicos das águas analisadas apresentaram classificação de baixo a médio potencial de dano ao sistema de irrigação, exceto o ferro total, que ficou na classificação de médio a alto potencial de dano por obstrução aos sistemas de irrigação localizada. Em seu trabalho consideraram ainda que não havia o risco de salinização do solo baseado nos valores medidos de condutividade elétrica.

Um grande risco que se corre quando se tem uma nascente protegida é a falsa ilusão de que a água advinda desse manancial ser limpa. Os agricultores em sua maioria por desconhecimento têm forte tendência a confiar e consumir essa água sem tratamento. Mas estudos, como o conduzido por Da Rocha et al. (2006) na zona rural de Lavras, tendo feito amostragens em nascentes constataram que nas análises de água realizadas, $93 \%$ das amostras apresentaram número de coliformes fecais acima do padrão de potabilidade, de acordo com a Portaria n. 36, com valores também superiores aos estabelecidos para os corpos d'água da classe 2, de acordo com a Resolução CONAMA n. 357. Também ficaram fora do padrão: oxigênio dissolvido $(87 \%)$; turbidez $(70 \%)$; ferro total $(60 \%)$; cor (57\%); pH (47\%) e sólidos totais (3\%).

Registros de vazão na bacia hidrogáfica do ribeirão São Bartolomeu, feitos pela UFV no período de seca nos anos de 70 a 90 registraram 12.000L.min-1 e em 2009 a vazão registrada foi 6.000L.min-1. As atividades de Desmatamento; Sobrepastejo; Fogo e a Monocultura, aliados à descapitalização do agricultor foram apontados como causadores desse decréscimo de vazão. GOMES et al. (2012) em seu trabalho na bacia hidrográfica do Araújos, Viçosa - MG , com o afluente do córrego da Mata do Paraíso que deságua no Ribeirão São Bartolomeu, em uma bacia de área 51,3ha, e após instalação do sistema de monitoramento foram implantadas técnicas de conservação de solo e água em algumas áreas da Bacia Hidrográfica quais sejam: terraços, curvas de nível, caixas de captação de água e reflorestamentos. Comprovaram que a retenção de água do escoamento superficial pelas técnicas de conservação de solo reflete em aumento da recarga do lençol freático e de forma direta nas vazões do manancial ao longo do ano. A redução nos picos de vazão refletiu no aumento de vazão mínima, mensurada no período de estiagem Com as práticas implementadas houve redução no escoamento superficial em aproximadamente $55 \%$. Suas conclusões foram que as práticas de conservação de solo e água adotadas, influenciaram: Retenção do escoamento superficial; aumento da infiltração e maior recarga dos lençóis freáticos

São 29.005, dentre eles: agricultores, técnicos e atores locais envolvidos em ações de capacitação e treinamento. 


\subsection{Macaé e o programa Rio Rural}

Como podemos observar na Tabela 3, Macaé foi selecionado com a posição $20^{\circ}$ município em prioridade de atendimento na área focal de prioridade 1 do programa.

Em Macaé, apenas duas microbacias foram trabalhadas durante a fase GEF do Rio Rural, a do Rio Dantas (2008) e Rio do Lírio (2009), estas encontram-se também no Rio Rural Bird, tendo recebido ano passado oitenta kits para a construção de fossas biodigestoras modelo Embrapa. Os subprojetos implantados têm sido acompanhados e novos beneficiários têm sido identificados, gerando novos sorteios e demandas.

Depois foi a vez das microbacias do Rio do Ouro, Rio Sana e Alto São Pedro (2010). A microbacia Canal Jurumirim foi iniciada em 2011. Mais recentemente, em 2014, a microbacia Canal Sabiá iniciou o trabalho.

\section{Material e métodos}

Este trabalho foi construído com vários procedimentos metodológicos, entre eles:

(i) pesquisa exploratória de gabinete com revisão bibliográfica sobre as temáticas abordadas no trabalho e pesquisa documental através de dados secundários fornecidos pelo IBGE, CEDRO e pelo INCRA -RJ, em relação ao assentamento;

(ii) pesquisa documental através de dados secundários fornecidos pelo Rio Rural e funcionários da EMATER - RIO, envolvidos no trabalho com as microbacias;

(iii) reconhecimento de campo com coleta de informações e relatos de experiências através de entrevista com informantes-chave;

(iv) coleta de informações através de entrevista com os técnicos executores do programa;

(v) relato pessoal de experiência do trabalho de campo com o Rio Rural.

\section{Resultados e discussão}

\subsection{A Microbacia Hidrográfica Canal Jurumirim}

Com uma área de 12.900 hectares, a microbacia localiza-se na bacia hidrográfica do Rio Macaé, subbacia do Rio do Ouro.

Devido à identidade social, escolhe-se para o trabalho o Assentamento Prefeito Celso Daniel, implementado em Macaé no ano de 2002/2003. Possui uma área total de 2.849,473 hectares situando-se nos municípios de Macaé, Conceição de Macabu e Carapebus. São 204 famílias assentadas nesse setor, sendo que cada lote varia de seis a doze hectares. Observando-se o Plano de Desenvolvimento Sustentável de constituição do Assentamento (PDA) nota-se que a produção de gêneros alimentícios é bem significativa, compreendendo mandioca, inhame, hortaliças, além de bovinocultura leiteira, criação de aves e piscicultura (CEDRO, 2006). Os produtores rurais desse assentamento abastecem boa parte da demanda de hortaliças da Secretaria Municipal de Educação de Macaé.

O marco inicial do programa foi a reunião de apresentação e adesão da microbacia realizada em 20/02/2011, com a presença de 103 pessoas. As Figuras 3 a 5 capturaram esses momentos. Na figura 3 
vemos uma panorâmica dos presentes; na figura 4 o momento das assinaturas e na figura 5 os agricultores levantando as mãos para sinalizar a adesão ao programa.

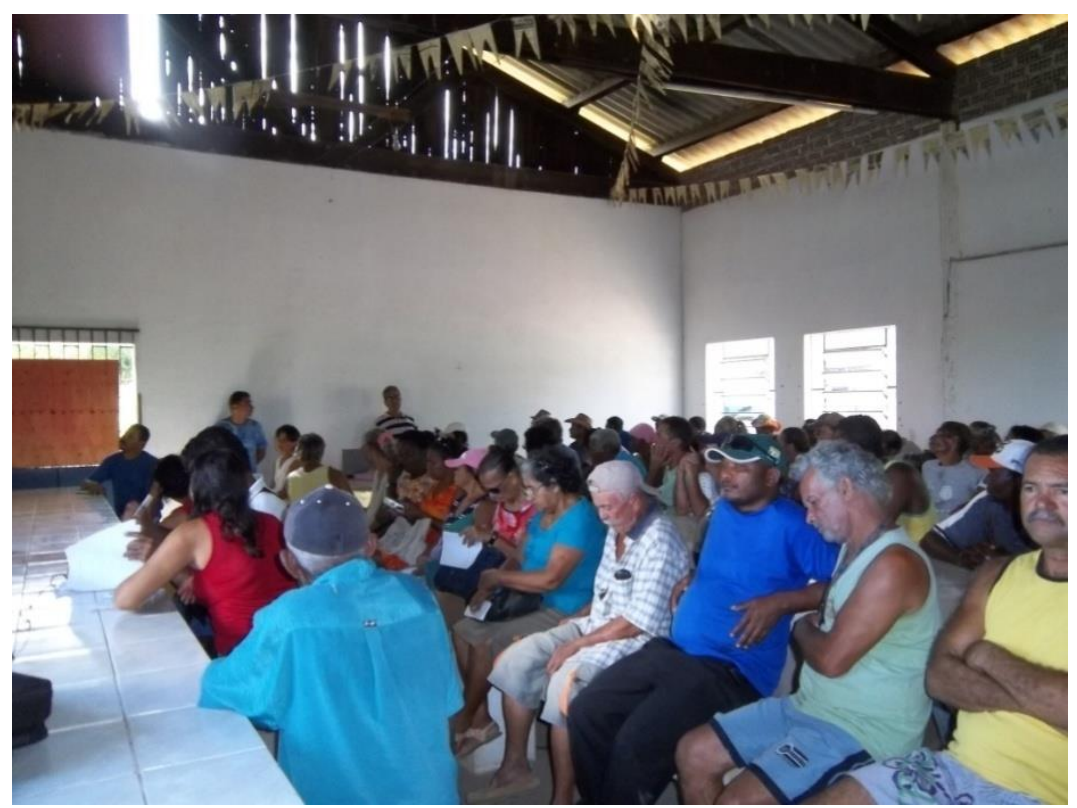

Figura 3 - Foto da reunião de adesão da microbacia Canal Jurumirim, na sede da Associação dos Moradores e Produtores Rurais do Assentamento Prefeito Celso Daniel, em 20/02/2011. Momento de exposição do programa.

Fonte: acervo próprio.

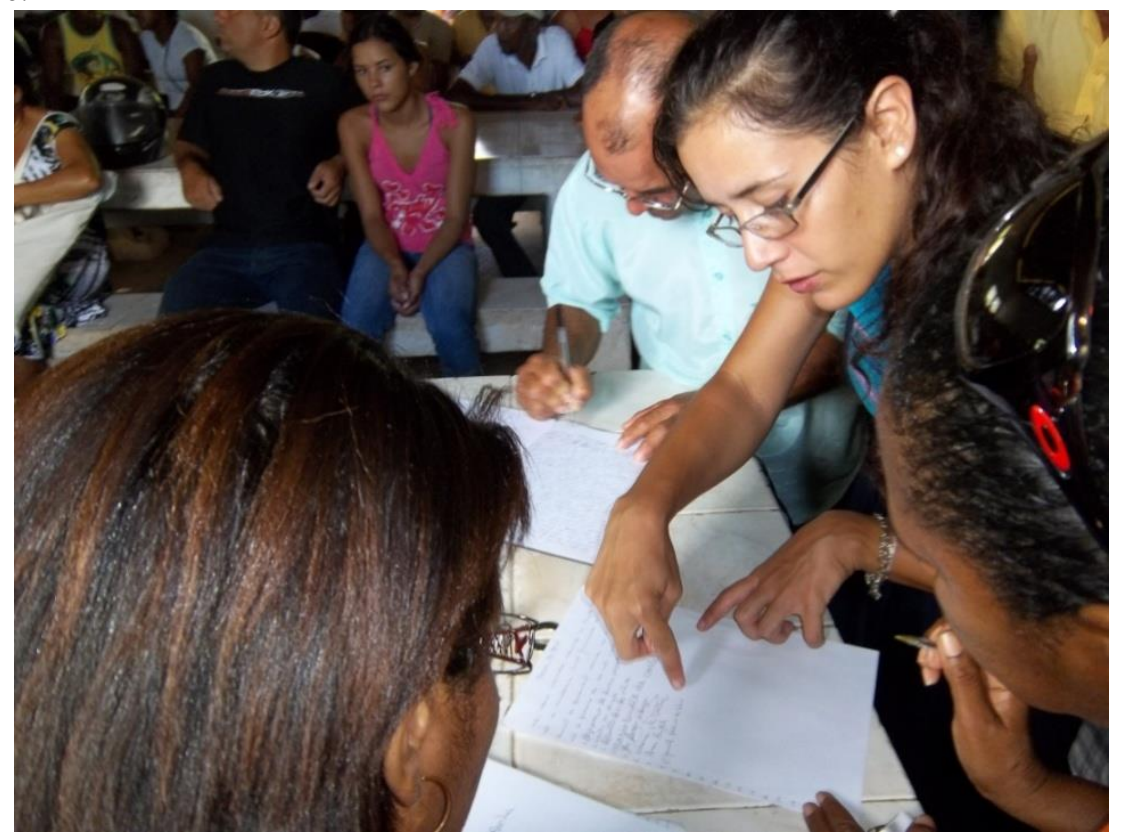

Figura 4 - Foto da reunião de adesão da microbacia Canal Jurumirim, na sede da Associação dos Moradores e Produtores Rurais do Assentamento Prefeito Celso Daniel, em 20/02/2011. Momento de coleta de assinaturas.

Fonte: acervo próprio. 


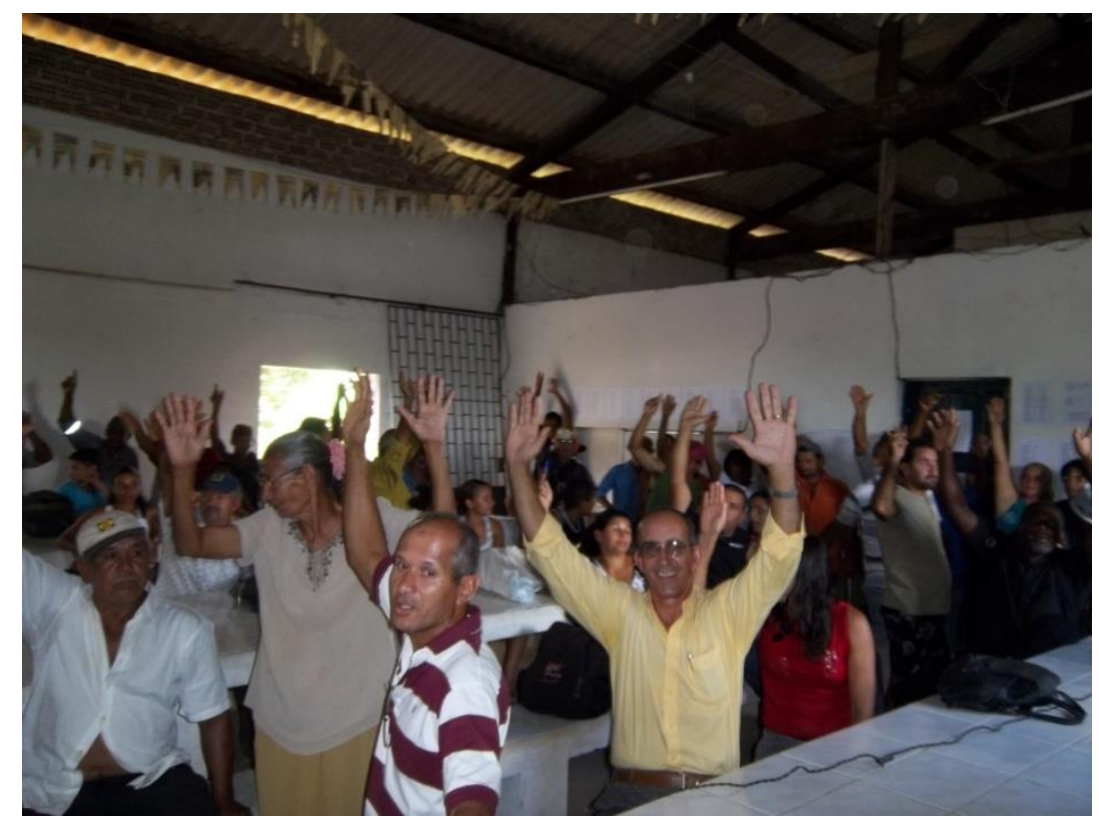

Figura 5 - Foto da reunião de adesão da microbacia Canal Jurumirim, na sede da Associação dos Moradores e Produtores Rurais do Assentamento Prefeito Celso Daniel, em 20/02/2011. Momento de adesão ao programa.

Fonte: acervo próprio.

A partir daí, foi feito o Diagnóstico Rural Participativo - Censo e eleição do COGEM em 13/04/2011. Os Diagnósticos Rurais Participativos foram feitos em três reuniões, onde foram ouvidos os três segmentos da comunidade, a saber: Cabiúnas 1, Cabiúnas 2 e Maria Amalha, num total de sete reuniões. Como pode ser observado na Figura 6, a participação nas reuniões de Diagnóstico foi bastante expressiva.

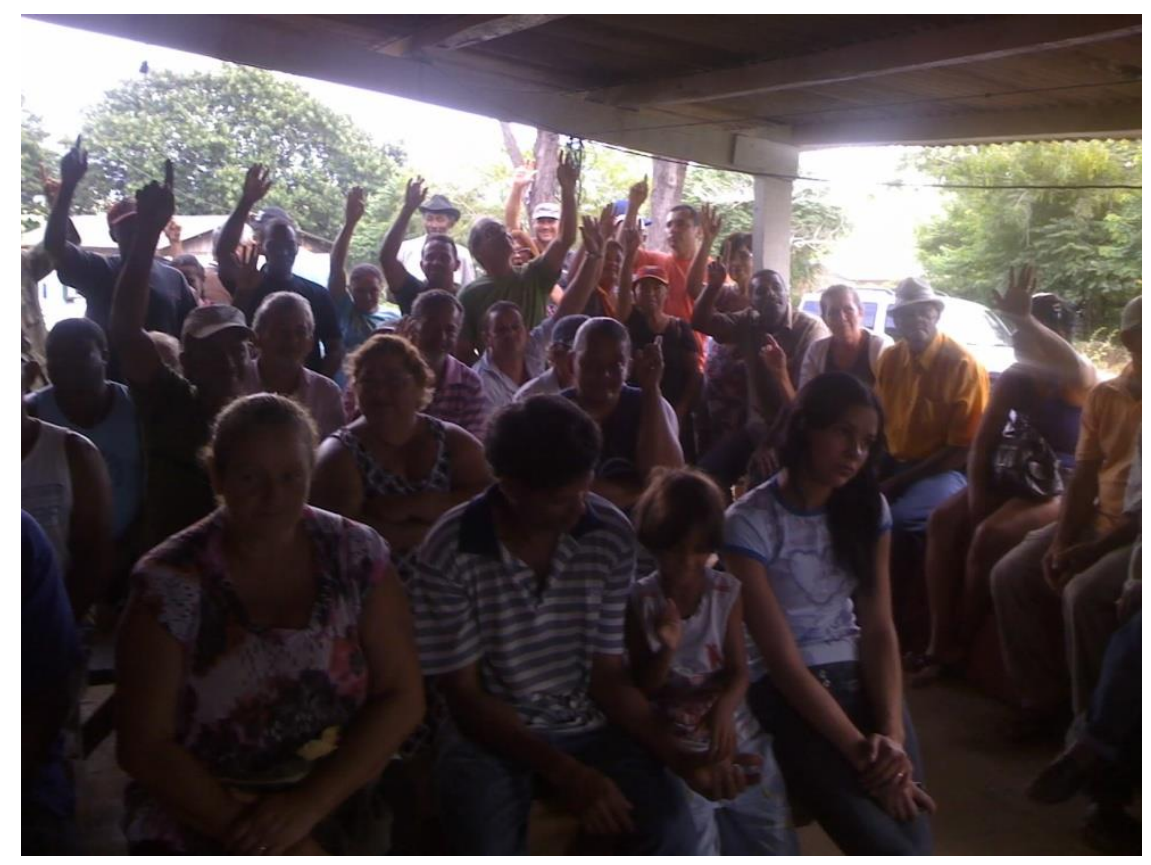

Figura 6 - Foto da reunião elaboração do DRP da microbacia Canal Jurumirim, na sede da Associação dos Moradores e Produtores Rurais do Assentamento Prefeito Celso Daniel, em 27/04/2011. 
Fonte: acervo próprio.

Em 12/07/2011, foi feita a apresentação do Plano Executivo da Microbacia elaborado. Seguiram-se oito reuniões do Cogem para priorização dos nomes e confecção da primeira lista para sorteio, a qual foi validada pela comunidade em 13/10/2011. Em 19/10/2011 os produtores constantes na primeira lista fizeram sua opção prévia por subprojetos e o sorteio para atendimento ocorreu em 03/11/2011. A partir de então, os Planos Individuais de Desenvolvimento vêm sendo feitos por visitas aos agricultores familiares seguindo rigorosamente a ordem de sorteio. $\mathrm{O}$ Cogem reúne-se periodicamente, estando no segundo mandato e o acompanhamento é feito junto aos agricultores já contemplados por meio de reuniões, visitas e conversas.

A comunidade possui 204 famílias e já foram elaborados 35 PIDs (Planos Individuais de Desenvolvimento) e liberados aproximadamente $\mathrm{R} \$$ 89.098,00 em recursos, com incentivo de 38 subprojetos.

\subsection{Relatos de experiências}

Estando presente desde a primeira reunião do programa, o agricultor familiar assentado da reforma agrária, Nilson Gomes dos Santos e sua esposa Rosimelia Constantino Lopes de Souza, têm implantado em sua propriedade os subprojetos de recuperação da mata ciliar com cercamento e plantio e kit galinha caipira. Muito atuantes na comunidade e sendo fornecedores de alimentos para a merenda escolar pelo PNAE - Programa Nacional de Alimentação Escolar, foram escolhidos para compor a primeira lista de sorteio, sendo contemplados no primeiro grupo. Senhor Nilson lembra da espera que caracterizou fé nas palavras da técnica executora do programa e continuou a participar das reuniões. Hoje seus projetos estão em pleno funcionamento, com expansão do galinheiro para suprir a demanda por ovos caipiras, e algumas gerações de galinhas depois. Tornaram-se referência na execução dos projetos, recebem constantemente a visita de vizinhos interessados em aderir ao programa, e outros, já contemplados, que vêm trocar experiências e impressões.

Uma história de superação, que encantou os membros do Cogem em uma das visitas de supervisão, foi da assentada Maria Aparecida Stica Ribeiro da Silva e seu cônjuge Wilson Ribeiro da Silva. Logo após a liberação do recurso, Maria Aparecida foi acometida por um AVC, que requereu hospitalização e muitos cuidados. Com o apoio do marido, está retomando aos poucos sua atividade, sem jamais perder o bom humor e a atitude positiva. Solicitaram dilatação do prazo para a prestação de contas e execução dos projetos e hoje já finalizaram a construção do galinheiro do kit galinha caipira e estão com todos os materiais comprados para a proteção de nascentes.

Outro militante no Cogem, em seu segundo mandato, Carlos Renato da Silva e sua esposa Rosiane Medeiros Laurindo Silva comemoram a liberação do recurso para a implantação da mata ciliar. Uma vontade antiga dos dois era recuperar a parte ambiental da propriedade e com o incentivo implantaram prontamente o projeto, recorrendo também à secretaria de agroeconomia de Macaé para fornecimento de mais mudas para enriquecer o ambiente. Muito embora tenha perdido algumas mudas para a seca que enfrenta o assentamento, o produtor replantou as que foram perdidas.

O senhor Arenilto Gomes da Silva e sua esposa Sonia Maria de Pinho da Silva foram contemplados com recursos para os subprojetos: recuperação da mata ciliar com cercamento e plantio e kit galinha caipira. São vizinhos da lagoa mais importante presente no assentamento e Arenilto declara a respeito do kit galinha caipira que para eles, o programa é uma bênção, só podem falar bem. Tudo o que vem 
para ajudar é bem vindo e que o programa os ajuda, e com essa mão eles vão pra frente. As franguinhas já começaram a pôr, e, das cinquenta que foram compradas, dez já estão pondo. Sobre a recuperação da mata ciliar, diz que a pessoa tendo o programa ou não, precisamos incentivar porque é uma coisa que todos nós precisamos. A Ampla (concessionária da rede elétrica) teve até que cortar uma árvore sua por estar muito próxima ao fio e ele solicitou ao funcionário duas no lugar. E relembra, com visível orgulho que ele e sua esposa receberam dois ônibus cheios de crianças no último ano, 2014, um de manhã, o outro à tarde, para ver a horta e as árvores. Os alunos tiveram a oportunidade de fazer canteiro, plantar e colher e agora sabem o que é abacate, manga, acerola etc. Contou também que aparece no site da secretaria de agroeconomia (de Macaé)". Na Figura 7 abaixo, senhor Arenilto aparece com os companheiros da associação.

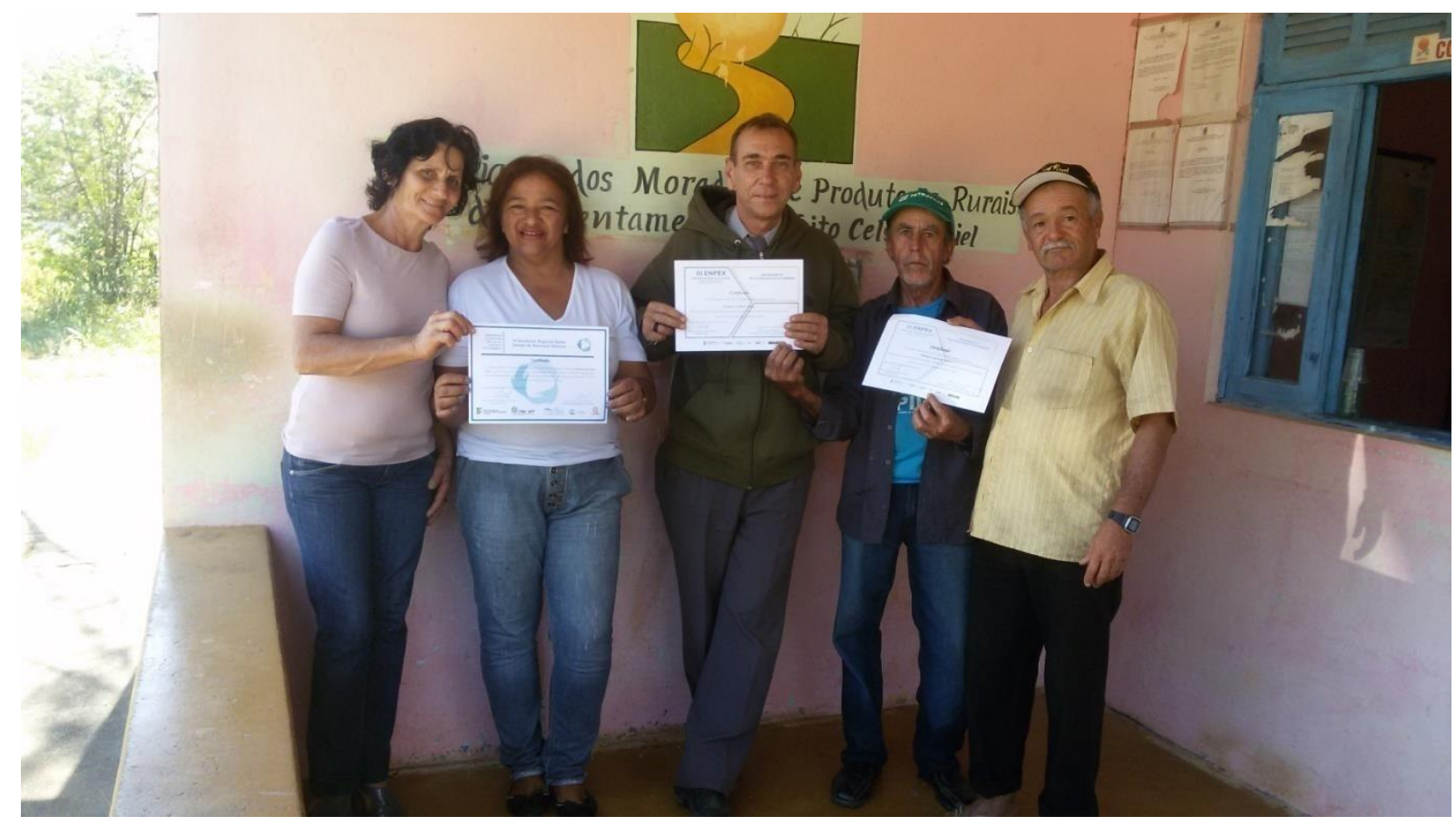

Figura 7 - Foto de produtores da microbacia Canal Jurumirim, na sede da Associação dos Moradores e Produtores Rurais do Assentamento Prefeito Celso Daniel, exibindo diplomas de participação em cursos. Da esquerda para a direita: Salvadora Pinto Santana, Marilucia Aparecida Soares, Paulo Jorge da Costa Bocorni, o "paulinho" - atual presidente da associação, Arenilto Gomes da Silva e Luiz Raimundo da Silva, o "pé de lã" - militante desde as primeiras reuniões para formação da invasão que deu origem ao assentamento.

Fonte: acervo próprio.

Nota-se a melhora na autoestima do agricultor familiar, por poder realizar sonhos e se sentir-se participante da melhoria ambiental do seu entorno. Muitos aguardam financiamento do PRONAF Programa Nacional de Fortalecimento da Agricultura Familiar, para executar seus projetos produtivos e o recurso do Rio Rural vem auxiliar a preencher demandas como essas, que às vezes demoram para ser operacionalizadas.

A agricultora familiar e membro da atual gestão da Associação dos Moradores e Produtores Rurais do Assentamento Prefeito Celso Daniel, Marilucia Aparecida Soares e seu esposo Francisco Carlos Fernandes Soares declara que apesar de não ter sido contemplada pelo programa, sente-se muito feliz pelas pessoas que já foram contempladas. Diz que as visitas que eles têm a oportunidade de fazer nas cidades circunvizinhas são muito construtivas. E cita como exemplo a que ocorreu no município de Campos, em Dores de Macabu, quando foram visitar em um dia de campo promovido 
pela EMATER - RJ um pastoreio rotacionado. Tiveram a oportunidade de conhecer um novo tipo de capim, e ficaram tão empolgados, ela e seu esposo que resolveram fazer esse trabalho de rotativo no sítio, onde criam dez carneiros. Já pensando em quando sair seu projeto, começaram a plantar algumas mudas no local da mata ciliar e Marilucia fez até um curso sobre isso no Campus Rio Paraiba do Sul/UPEA do IFF (Instituto Federal Fluminense). Ela diz que gosta muito de participar desses cursos pois eles contribuem na sua formação de graduação em licenciatura em educação no campo com ênfase em agroecologia e segurança alimentar que concluiu em 2013 pela FETAG (Federação dos Trabalhadores na Agricultura) e INCRA (Instituto Nacional de Colonização e Reforma Agrária) em regime de alternância e minha pós em engenharia ambiental, que faço aos sábados desde 2014 . Na figura 8, foto onde aparece Marilucia no dia de campo citado.

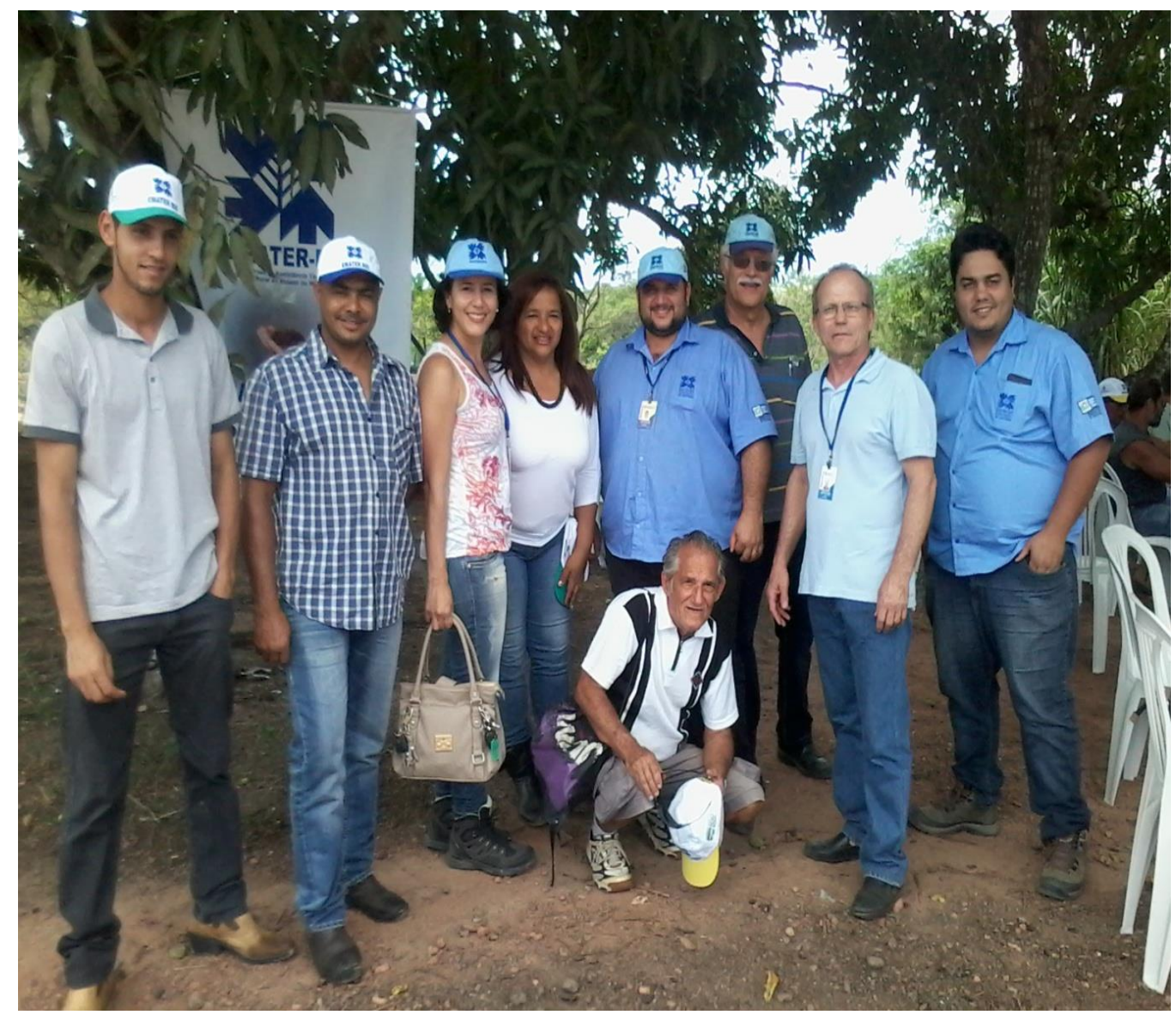

Figura 8: Foto de assentados e técnicos da EMATER-RIO em dia de campo promovido pelo escritório local de Campos dos Goytacazes em Dores de Macabu em 18/11/2014. Da esquerda para direita: Ismael Barros, Marcos Antonio Silveira de Sou za, Ana Rita Moreira Rangel (esloc MC), Marilucia Aparecida soares, Flaviano (esloc MB), Renato (esloc CP), Geraldo Monteiro (esloc CP), Pedro (esloc MB), abaixado Mauricio Fernandes.

Fonte: Acervo pessoal

As constantes excursões e cursos promovidos pelo programa ou em parceria visam estimular os agricultores, trazerem novidades, promover a troca das experiências e capacitá-los para desenvolvimento de suas atividades de maneira proativa. 


\section{Conclusões}

Mais do que implementar projetos de conservação hídrica, a estratégia de metodologia participativa por meio da microbacia hidrográfica, usada no programa Rio Rural, promove a conscientização e comprometimento do agricultor familiar com a preservação dos recursos naturais e adoção de práticas econômicas sustentáveis.

Até agosto de 2015, os incentivos financeiros diretos não reembolsáveis do programa beneficiaram 1.661 produtores no estado do Rio de Janeiro, os quais receberam o total de R \$ 3,1 milhões para a execução das ações conservacionistas.

Em Macaé, apenas duas microbacias foram trabalhadas durante a fase GEF do Rio Rural, a do Rio Dantas (2008) e Rio do Lírio (2009), depois foi a vez das microbacias do Rio do Ouro, Rio Sana e Alto São Pedro (2010). A microbacia Canal Jurumirim foi iniciada em 2011 e mais recentemente, em 2014, a microbacia Canal Sabiá iniciou o trabalho.

A comunidade trabalhada na microbacia Canal Jurumirim é o Assentamento Prefeito Celso Daniel, que possui 204 famílias. Já foram elaborados 35 PIDs (Planos Individuais de Desenvolvimento) e liberados aproximadamente $\mathrm{R} \$ 89.098,00$ em recursos, com incentivo de 38 subprojetos.

Observou-se que de modo geral a comunidade encontra-se satisfeita com o incentivo financeiro proporcionado pelo programa. A percepção do ganho ambiental é bastante alta, com os projetos de recuperação da mata ciliar, com cercamento e plantio, proteção de nascentes e sistemas agroflorestais, principalmente. Dos subprojetos de cunho produtivo, os mais acessados são o kit galinha caipira, pastoreio rotacionado e implantação de nova atividade diversificada. Nota-se a ansiedade dos envolvidos em que todos sejam contemplados pois o número de famílias é alto e existe uma ordem imposta por sorteio para atendimento.

Por outro lado, existem alguns beneficiários que foram contemplados e desistiram do projeto, como o caso da senhora Francisca Silva da Cruz, a "dona Chica", que decidiu devolver o recurso por problemas pessoais. Outros vieram a óbito após a liberação do recurso financeiro, e antes de finalizarem a prestação de contas e implantação dos subprojetos incentivados, como o caso de José Cândido do Nascimento Filho, o "goiaba" e Avelino Pinheiro Ramos, ficando o primeiro caso em aberto e o segundo depois seus filhos resolveram assumir e lhes foi dado um novo prazo para conclusão.

Ainda outros receberam o recurso e não implantaram os projetos total ou parcialmente, ou mesmo apresentaram prestação de contas fora dos padrões exigidos, o que gera sucessivas visitas periódicas, tanto do técnico executor como dos membros do Cogem tentando ajudar e animar esses indivíduos para a conclusão satisfatória, antes que os mesmos tenham que ser notificados de execução judicial por responsabilidade.

\section{Referências}

ALVES, S. C. A água como elemento fundamental da paisagem em microbacias. Informe Agropecuário, Belo Horizonte, v. 21, n. 207, p. 9-14, nov./dez. 2000.

BRASIL. Lei no 4.771, de 15 de setembro de 1965. Institui o novo Código Florestal. Diário Oficial da União, Brasília, 16 set. 1965.

BRASIL. Portaria n. 36 do Ministério da Saúde, de 19 de janeiro de 1990. Diário Oficial da União 1990; 
23 jan

Resolução CONAMA n. 357/2005. Dispõe sobre a classificação dos corpos de água e diretrizes ambientais para o seu enquadramento, bem como estabelece as condições e padrões de lançamento de efluentes, e dá outras providências. Diário Oficial da União 2005; 18 mar.

CEDRO. Plano de Desenvolvimento Sustentável do Assentamento Prefeito Celso Daniel -PDA. Macaé, mimeo. 2006.

FRANCO, R. A. M.; HERNANDEZ, F. B. T. Qualidade da água para irrigação na microbacia do Coqueiro, Estado de São Paulo. Revista Brasileira de Engenharia Agrícola e Ambiental, v.13, p.772780, 2009.

GOMES, M. A.; LANI, J. L.; COSTA, L. M. DA; et al. Solos, manejo e aspectos hidrológicos na bacia hidrográfica do Araújos, Viçosa - MG. Revista Árvore, v. 36, n. 1, p. 93-102, 2012.

KUMMER, L. Metodologia participativa no meio rural: uma visão interdisciplinar: Conceitos, ferramentas e vivências. Salvador: GTZ, 2007. 155p.

PINTO, L. V. A.; ROMA, T. N. DE; BALIEIRO, K. R. DE C. Avaliação qualitativa da água de nascentes com diferentes usos do solo em seu entorno. CERNE, v. 18, n. 3, p. 495-505, 2012. Universidade Federal de Lavras. Disponível em: <http://www.scielo.br/scielo.php?script=sci_arttext\&pid=S010477602012000300018\&lng=en\&nrm=iso\&tlng=pt>. Acesso em: 19/1/2016.

RAMOS, P. R.; RAMOS, L. A.; LOCH, C. Sensoriamento remoto como ferramenta para a gestão ambiental e o desenvolvimento local. In: CONGRESSO BRASILEIRO DE CADASTRO TÉCNICO MULTIFINALITÁRIO, 2004, Florianópolis. Anais... Florianópolis: UFSC, 2004. p. 1-7.

RIO RURAL. Projeto Desenvolvimento Rural Sustentável. Secretaria de Agricultura, Pecuária, Pesca e Abastecimento / Superintendência de Desenvolvimento Sustentável. 2009. P. 99.

Rio Rural alcança meta de $\mathbf{2 0 1 6}$ nascentes protegidas um ano antes do previsto. Rio de Janeiro, 05 de agosto de 2015. Disponível em <http://www.microbacias.rj.gov.br/pt/noticia/810/riorural-alcanca-meta-de-2016-nascentes-protegidas-um-ano-antes-do-previsto\#sthash.56WPTprd.dpuf . Acesso em 07 de agosto de 2015.

Da ROCHA, C. M. ; RODRIGUES, L. D. S. ; COSTA, C. C. ; De OLIVEIRA, P. R. ; Da SILVA, I. J. ; De JESUS, É. F. M. ; ROLIM, R. G. Cadernos de Saúde Publica, 2006, Vol.22(9), pp.1967-1978

DE SOUZA, L. M.; FARIA, R. A. V. B.; BOTELHO, S. A.; FONTES, M. A. L.; FARIA, J. M. R. Potencial da regeneração natural como método de restauração do entorno de nascente perturbada. Cerne, v. 18, n. 4, p. 565-576, 2012.

VERDEJO, M. E. Diagnóstico Rural Participativo: guia prático DRP. Brasília: MDA/Secretaria da Agricultura familiar. 2006, p. 65. 